\title{
MOTIVATION, SUPERVISION, AND ADHERENCE TO MEDICAL WASTE POLICY IN SOUTH LABUHAN BATU, NORTH SUMATERA
}

\author{
Syahrul An, Irnawati Marsaulia, Destanul Aulia
}

Masters Program in Public Health, Universitas Sumatera Utara

\begin{abstract}
Background: Medical waste is unwanted biological products that are highly infectious in nature. It is broadly classified as infectious waste and biohazardous waste, and can easily spread any disease virally and can even pose a danger to life. Medical waste is found in hospitals, laboratories, research centres, tattoo parlours, etc. It has to be disposed properly otherwise it poses a health and environmental danger. This study aimed to examine the effects of motivation and supervision on adherence to medical waste policy in South Labuhan Batu, North Sumatera.

Subjects and Method: This was a cross-sectional study carried out in South Labuhan Batu, North Sumatera. A sample of 85 health care workers were selected for this study, consisting of health center doctors, private doctors, and health clinic owner. The dependent variable was adherence to medical waste policy. The independent variables were motivation and supervision. The data were collected by questionnaire and analyzed by multiple logistic regression.

Results: Adherence to medical waste policy was affected by strong motivation $(\mathrm{OR}=6.31 ; 95 \% \mathrm{CI}=2.74$ to $9.33 ; \mathrm{p}=0.048)$ and regular supervision $(\mathrm{OR}=5.56$; $95 \% \mathrm{CI}=3.42$ to $8.09 ; \mathrm{p}=0.039$ ).

Conclusion: Adherence to medical waste policy is affected by motivation and supervision.

Keywords: waste policy, adherence, motivation, supervision.

\section{Correspondence:}

Syahrul An. Masters Program in Public Health, Universitas Sumatera Utara, Medan, North Sumatera. Email: 44nregar@gmail.com. Mobile: 082366502449.
\end{abstract}

